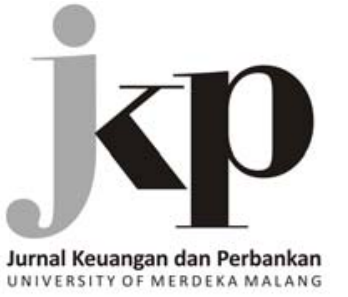

Article history:

Received: 2019-07-05

Revised: 2019-08-13

Accepted: 2019-10-02

Keywords:

Efficiency; Microfinance

institution; Rural finance;

Sustainability; SFA

JEL Classification: G21, G23

Kata kunci:

Efisiensi; Lembaga keuangan

mikro; Pembiayaan pedesaan;

Berkelanjutan; SFA

$\triangle$ Corresponding Author:

Triane Widya Anggriani:

Tel +62 2518622642

E-mail: trianewidya@gmail.com

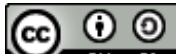

This is an open access

article under the CC-BY-SA license

\section{Efficiency and sustainability of microfinance: Study case agribusiness microfinance institutions in Bogor}

\author{
Triane Widya Anggriani ${ }^{1}$, R. Nunung Nuryartono ${ }^{2}$, Bambang Juanda ${ }^{2}$, \\ Jaenal Effendi² \\ ${ }^{1}$ Center of Agricultural Training, Management, and Leadership, Ministry of Agriculture \\ Jl. Raya Puncak Km. 11, Bogor, 16720, Indonesia \\ ${ }^{2}$ Faculty of Economics and Management, IPB University \\ Jl. Raya Dramaga, Kampus IPB Dramaga Bogor, 16680, Indonesia
}

\section{Abstract}

Microfinance is one of the solutions in poverty alleviation in rural areas. The existence of financial access in a rural area, with hope, low-income society can increase their revenues and eventually able to escape the circle of poverty. The agribusiness microfinance institution is the institution that provides financing services to farmers in rural areas. However, agribusiness microfinance institution is facing sustainability problems. We analyzed financial sustainability in terms of the cost-efficiency of the Agribusiness Microfinance Institution (AMFI). The study utilized a parametric approach method of Stochastic Frontier Analysis (SFA). The sampling technique used was purposive sampling, namely AMFI possessing two years of financial reports (in the year 2016-2017) around Bogor District, there were fifteen AMFIs qualified. The result indicates AMFIs' efficiency value in Bogor District almost approaching 100\%. It means that the AMFIs' financial performance in Bogor District was highly efficient. Labor cost is a very responsive variable in the total cost. However, AMFIs' labor cost was low. This matter caused administrator performance in servicing their customers to become not optimal, thus impacting the unsustainability of AMFI.

\section{Abstrak}

Keuangan mikro adalah salah satu solusi dalam pengentasan kemiskinan di daerah pedesaan. Keberadaan akses keuangan di daerah pedesaan, dengan harapan, masyarakat berpenghasilan rendah dapat meningkatkan pendapatan mereka dan pada akhirnya mampu keluar dari lingkaran kemiskinan. Lembaga keuangan mikro agribisnis adalah lembaga yang menyediakan layanan pembiayaan kepada petani di daerah pedesaan. Namun, lembaga keuangan mikro agribisnis menghadapi masalah keberlanjutan. Kami menganalisis kesinambungan keuangan dalam hal efisiensi biaya dari Lembaga Keuangan Mikro Agribisnis (AMFI). Penelitian ini menggunakan metode pendekatan parametrik dari Stochastic Frontier Analysis (SFA). Teknik pengambilan sampel yang digunakan adalah purposive sampling, yaitu AMFI yang memiliki dua tahun laporan keuangan (pada tahun 2016-2017) di sekitar Kabupaten Bogor, ada lima belas AMFI yang memenuhi syarat. Hasilnya menunjukkan nilai efisiensi AMFI di Kabupaten Bogor hampir mendekati 100\%. Ini berarti bahwa kinerja keuangan AMFI di Kabupaten Bogor sangat efisien. Biaya tenaga kerja adalah variabel yang sangat responsif dalam total biaya. Namun, biaya tenaga kerja AMFI rendah. Hal ini menyebabkan kinerja administrator dalam melayani pelanggan mereka menjadi tidak optimal, sehingga berdampak pada tidak berkelanjutannya AMFI.

How to Cite: Anggriani, T. W., Nuryartono, R. N., Juanda, B., \& Effendi, J. (2019). Efficiency and sustainability of microfinance: Study case agribusiness microfinance institutions in Bogor. Jurnal Keuangan dan Perbankan, 23(4), 540-552. https://doi.org/10.26905/jkdp.v23i4.3591 


\section{Efficiency and sustainability of microfinance: Study case agribusiness microfinance institutions in Bogor \\ Triane Widya Anggriani, R. Nunung Nuryartono, Bambang Juanda², Jaenal Effendi}

\section{Introduction}

Poverty has always been a fundamental and global problem which become the center of attention of the government at the moment. BPS data (2017) shows that most of the poor populations occur in rural areas, and their livelihood was in the agricultural sector. Bogor District is one of the area with high-level poverty in West Java Province. BPS data (2017) stated that the number of poor inhabitant in Bogor District in 2016 were as much as 490,80 (in thousand, inhabitants). The number of poor inhabitants in the Bogor District was the most significant compared to other districts in West Java province (BPS, 2016). On the other hand, in terms of Gross Regional Domestic Product (GRDP) in 2016, Bogor District was the top three contributors of $(11,18$ percent) to West Java province after Bekasi District of (15.86 percent) and Bandung City of (13.13 percent). However, when it came to GRDP per capita in 2016, Bogor District occupies the ninth level in West Java Province, which reached 33.05 million Rupiah per year, lower than GRDP per capita of West Java Province which already in the level of 34.88 million Rupiah per year. In terms of Human Development Index (HDI) achievement, Bogor District with 68.32 was still under the HDI average of West Java Province with 70.05 (BPS, 2016).

Observing the economic condition in Bogor District, indicating an ironic condition, considering the high number of GRDP nominal value of Bogor District, on the contrary, the GRDP per capita and HDI value was low. GRDP development apparently has not helped much in escalating GRDP per capita development. Besides that, in terms of banking credit proportion in commercial banks based on the economic sector in 2017, showed that trading, hotel and restaurant sector obtained the most significant credit proportion of 52.39 percent, while the agriculture sector only gets 1.75 percent (BPS, 2017). Inequality credit for the agriculture sector indicating that the access to formal financial services in the agriculture sector was still limited.
Most of the poor inhabitants were farmers who live in rural areas. Farmers encounter four agriculture problems namely: (1) the average of agricultural land area was small with low productivity; (2) farmers facing limitation of access to agricultural information and technology; (3) farmers having obstacles of human resources availability; and forth, the fundamental problems to most of the Indonesian farmers are the capital limitation possessed by the farmers (Anantanyu, 2011). Various conditions above caused farmers unable to expand their scale of business due to the unavailability of savings to subsequent reinvestment. If the situation continues, then it won't be impossible for farmers to be traped around in the circle of poverty (the equilibrium trap at the low level). Considering the vital role of the agriculture sector, thus, the problems faced by the farmers, therefore agricultural business development must receive financial support in the form of credit.

The existence of Agribusiness Microfinance Institutions (AMFIs) becomes one of the solutions in financing the agriculture sector in rural areas due to its strategic role as the connector for farmers society economic activities of rural areas. AMFI also play a role in strengthening farmer institution in developing agribusiness development which can not be separated from poor access for farmers through various productive resources, namely: capital, technology and market information (Hermawan \& Andrianyta, 2012).

Agribusiness Microfinance Institution is one of the breakthrough programs from the Ministry of Agriculture to reduce the number of farmers' poverty in rural areas through the Rural Agribusiness Development Program (RADP). Farmers group alliance who receive the RADP fund was expected to maintain fund rotation/cashflow until the establishment phase of the Agribusiness Microfinance Institution (AMFI) done. Growth and development of AMFI within the Farmers group alliance is one of the strategic stages to solve financing problems faced by micro farmers and farm workers who were hav- 
ing difficulties in obtaining financial services through a formal financial institution.

Based on the data established by Crop Food, Horticulture, and Plantation Agency of Bogor District, there were as many as 201 farmers' group alliances that have been given capital assistance from 2008 up to 2015, which spread in 30 sub-districts. It means that each farmers' group budgeted to obtain capital assistance as much as IDR 100,000,000, therefore, the total fund distributed in the whole Bogor District area has reached the value of 20.1 billion Rupiahs. However, the evaluation progress result reveals that since 2016, there were only 81 farmers' group alliances (40.3 percent) have been formed into AMFI. This indicated that several Agribusiness Microfinance Institutions have experience business sustainability problems.

Most microfinance institutions built by the governments' program was facing problems regarding their sustainable activities. The cause of the inability to maintain their sustainability can be formed in various conditions starting from dependency to government and donors' support or being a project which only designed temporarily, unavailability of an adequate microfinance system, and incompetence to adapt with the existed microfinance market situation. To encounter AMFIs' unsustainability problems, the strategy for AMFI capable of keeping sustainable is a necessity. It is also important to remember that microfinance activity can generate a significant contribution to poor people only if the microfinance services given sustainably.

Financial sustainability is a prerequisite for microfinance institutions in generating significant and long term contribution to reducing poverty. Financial sustainability determined by how efficient a microfinance institution is using its resources in providing financial services (Armendariz \& Labie, 2011; Mulyaningsih, 2016). Efficiency is a substantial factor for microfinance institutions' longterm sustainability (Masood \& Ahmad, 2010; Nuryartono, Anggraenie, \& Firdaus, 2012). Recognizing the de- fining factor of microfinance institutions' efficiency will help us to understand which factor determined financial sustainability, in turn, will escalate our comprehension regarding microfinance potential in generating contribution of poverty alleviation. Hence, the analysis in this study is focused on cost efficiency as the measurement of microfinance institutions' performance. Microfinance institutions demanded to be efficiency demands so it can operate sustainably and competitive with the market available. In regards to and considering the strategic value of Agribusiness Microfinance Institution as microfinance institution who have access to poor farmers in a rural area, then this study emphasizes on analyzing financial sustainability of agriculture microfinance institution in terms of efficiency.

The arrangement of this paper as follows: section 2 discussing relevant literature with the topic of financial sustainability in terms of microfinance institutions' efficiency; research methodology presented in section 3; section 4 presents research results; and section 5 showing detail discussion regarding the outcome of this study. Finally, the conclusion presented in section 6 , along with the further scope of research expansion.

\section{Hypotheses Development}

Microfinance is financial services for microbusinesses and households with low revenues (Morduch, 1998; Usman et al., 2004; Bakhtiari, 2006; Arsyad, 2008; Mersland \& Strøm, 2010). According to Arsyad (2008), microfinance considered a substantial element for an effective poverty alleviation strategy. Microfinance institutions characterized by several dynamic, innovative, and flexible regulation which designed following the condition of local social and economic environments. The idea of microfinance based on the concept that the inability of poor society in accessing financial services is a severe obstacle for their economy improvement, change of life, and obtaining resources to start and 


\section{Efficiency and sustainability of microfinance: Study case agribusiness microfinance institutions in Bogor \\ Triane Widya Anggriani, R. Nunung Nuryartono, Bambang Juanda², Jaenal Effendi}

develop their existing business to improve their economic condition (Zeller \& Meyer, 2002).

Microfinance reduces information and transaction cost, which was usually faced by the formal financial sector in servicing poor society in a rural area, thus with the existence of microfinance institution, the cost becomes more efficient. In regards to transaction cost, microfinance institution needs lower transaction cost instead of modern banks (Arsyad, 2008). First, a microfinance institution possesses better information regarding their customer compared to commercial banks, because the lender (the creditor) possessed pretty good information regarding debtor, which obtained from their relationship with the surrounding environment and their community or even from previous credit transactions. Automatically it would reduce information cost for microfinance institutions. Second, administration cost, which must be issued by microfinance institutions, is lower than commercial banks because micro finances' employees paid relatively cheaper due to their lower education level, smaller business scope, and more straightforward administration work. Third, the microfinance interest rate is not explicitly regulated; thus, it can be justified with market demand. Forth, microfinance institution did not have capital reserve obligation as it was applied for modern commercial banks.

The outreach of financial service improvement could not be achieved without financial sustainability (Sim \& Prabhu, 2014). Microfinance financial sustainability, or in another word refers to financial self-sufficiency, is a condition in which a microfinance institution can be totally cover all its operational costs and other expenses (bank loan fee and inflation cost) from interest ( Sim \& Prabhu, 2014). A microfinance institution is financially independent when the institution can grow its capital, making the capital separate from any donor nor government subsidy (Yaron, 1994). Being an independent microfinance institution financially is a tech- nique for the financial institution to grow and sustainable (Littlefield, Morduch, \& Hashemi, 2003).

Efficiency is crucial for microfinance institutions' long term sustainability. Sustainable outreach highly depends on microfinance institutions' financial sustainability. Efficiency will assist in discovering how microfinance institutions should utilize input such as labor and capital to produce output such as loans and deposits (Hartarska, Shen, \& Mersland, 2013). Efficiency extremely related to financial stability, where an efficient financial institution is a prerequisite for a stable financial system (Fitzpatrick \& McQuinn, 2005). A stable financial system will relatively more resistant to facing a crisis. Therefore, it is imperative to analyze the efficiency level to discover the stimulative factors of efficiency. Those factors can be the references in formulating strategies to improve efficiency.

Berger \& Mester (1997) were conducting research related to cost efficiency in a financial institution in the United States of America. Efficiency measurement of a financial institution with frontier methodology approach, namely: calculating individual production efficiency, which was measured by comparing with a certain standard. It means cost-efficiency calculated by comparing the cost of each financial institution/bank with their frontier function. Generally, frontier analysis divided into two outlines (Berger \& Humphrey, 1997), namely: parametric and non-parametric methods. Non-parametric method divided into two, which are Data Envelopment Analysis (DEA) and Free Disposal Hull (FDH). The parametric method divided into three approaches, namely Stochastic Frontier Analysis (SFA), Distribution Free Approach (DFA), and Thick Frontier Approach (TFA). Stochastic Frontier Model is an alternative model that allows the existence of inefficiency and error measurement.

Masood \& Ahmad (2010) was analyzing the efficiency of a micro-financial institution in India by using the Stochastic Frontier Analysis (SFA) tech- 
nique. The result of the research presented that the average level of proficiency in a micro-financial institution was low, but increasing over a specific period. The age and size of a micro-financial institution is a positive determinant of efficiency. Hermes, Lensink, \& Meesters (2011) were investigating the trade-off between efficiency and range over poor society by using cross country data panel with a population of 435 microfinance institutions period 1997 to 2007. They discover persuasive evidence of trade-off existence between range and efficiency; the study presenting that efficiency improvement can only be achieved when a microfinance institution less focused on poor society.

Dumilah, Juanda, \& Khayatun (2017) analyzing cost efficiency by using Stochastic Frontier Analysis (SFA) in Cooperative Baitul Maal Wat Tamwil (KBMT) of South Tangerang City, discovered the result of four KBMT in Tangerang City have an average efficiency cost almost approaching $100 \%$. This indicating that the efficiency level of Baitul Maal Wat Tamwil Institution in South Tangerang City was quite good. Suharyadi \& Sumarto (2017) were analyzing the cost efficiency of the banking industry in Indonesia. Research results indicating that the most efficient bank in terms of cost efficiency is the banks owned by the government (BUMN) compared to foreign banks.

Financial sustainability is a prerequisite to microfinance institutions in providing long term contributions through poverty alleviation. Financial sustainability determined by how much a micro- finance institution can be efficient in using its resources. Recognizing efficiency determinant factors helps us to comprehend what determined financial sustainability, in turn, will increase comprehension regarding microfinance potential in generating a contribution to cost efficiency as the measurement micro financial institution in poverty alleviation. Hence, this study is focusing on cost efficiency as microfinance institution performance measurement, which is providing financial services with the most efficient cost possible.

\section{Method, Data, and Analysis}

This research took place in Bogor District, West Java province. Research objects were Agribusiness Microfinance Institutions (AMFI). Sample collection technique in this study conducted by purposive sampling with the criteria of agribusiness microfinance institutions possessing complete financial statements/ reports for two years from 2016 to 2017. Survey result over 81 agribusiness microfinance institutions registered in Food Crop, Horticulture and Plantation Agency of Bogor District, there were only 15 agribusiness microfinance institutions that have complete data of financial reports.

Agribusiness microfinance institutions' efficiency analysis using the Stochastic Frontier Analysis (SFA) method. Stochastic Frontier Analysis (SFA) method was one of the efficiency measurement techniques based on the cost value of a company compared to its best practices. Efficiency measurement by using the SFA method is perceived to be more,

Table 1. Variable used in Stochastic Frontier Analysis (SFA)

\begin{tabular}{lll}
\hline \multicolumn{1}{c}{ Variable } & \multicolumn{1}{c}{ Operational Definition } & Hypothesis \\
\hline $\begin{array}{l}\text { Var. Dependent } \\
\text { Total Cost (TC) } \\
\text { Var. Independent }\end{array}$ & Operational and non operational cost (IDR) \\
Price of Labor (PLB) & Labor wages and salary cost (IDR) & - \\
Gross Loan Portfolio (GLP) & Total loan distributed to each member (IDR) & Positive \\
Total Equity (TEQ) & Capital (sourced from grants, principal savings, mandatory savings \\
& and reserve) (IDR) & Positive \\
\hline
\end{tabular}


and the measure also includes input and output factors, so it would generating a statistical conclusion. The reference used to determine the variables utilized in this study is Berger \& Mester (1997), Anggraenie, \& Firdaus (2012), Maesaroh (2013), Mulyaningsih (2016), Nuryartono. The variables used in this study are presented in Table 1.

By using agribusiness microfinance institution sample, thus the model of cost function equation of agribusiness microfinance institution as follows:

$$
\begin{aligned}
\operatorname{lnTC} C_{i t}= & \alpha_{0 i t}+\beta_{1} \ln P L B_{i t}+\beta_{3} \ln G L P_{i t}+\beta_{4} \ln T E Q_{i t} \\
& +\varepsilon_{i t}
\end{aligned}
$$

The specification model of agribusiness microfinance institutions' sustainability analysis in terms of efficiency is utilizing cost function. In this function, the total cost consisted of operational and non-operational expenses. The first dependent variable used in this study is the labor cost. Labor cost is the most influential variable in the total cost. The labor cost referred to in this study is the cost that must be given to the board member and employee who worked in an agribusiness microfinance institution. The second variable is total credit distributed to the customer. The total credit is the total amount of loan given to the customer within a year. The third variable is the total capital. The total capital consisted of the number of capital aid grants from the government, principal savings, mandatory savings, and reserved funds. Capital escalation will implicate agribusiness microfinance institutions' cost; this is the consequential total cost that must be spent for the maintenance of the capital mentioned.

The result of the cost function of frontier model, the model developed by Berger \& Mester (1997), where the cost function of all variables changed to the natural logarithm form. Another benefit, the transformation into the form of the logarithm is to overcome heteroscedasticity (Nachrowi \& Usman, 2002). The principal contained in this method is that transformation into logarithm form will generate a smaller value difference, thus the heteroscedastic data becoming homoscedastic data. Annual efficiency value by using SFA presented in the form of a percentage, which is approaching $100 \%$, indicating that an agribusiness microfinance institution was already running efficiently. As stated by Berger \& Mester (1997), cost efficiency is measuring how close financial institution cost compared with the cost of a financial institution whose operated at its best performance level that they produce the same output and similar condition. A financial institution is categorized as an inefficient one if the level of institution cost is higher compared to the frontier who operated at its best performance (best practice). The cost-efficiency of the agribusiness microfinance institution basically influenced by input and output variables, which will form the cost frontier prediction model, which will estimate and generated efficiency value; thus, a comparison can be made.

Mathematically cost efficiency of the agribusiness microfinance institution, according to Berger \& Mester (1997) is:

$$
\begin{aligned}
& \operatorname{Cost} E F F^{b}=\frac{\hat{\mathrm{C}}^{\text {min }}}{\hat{\mathrm{C}}^{b}} \\
& =\frac{\exp \left[f^{\wedge}\left(w^{b}, y^{b}, z^{b}, v^{b}\right)\right] \times \exp \left[\ln \hat{\mathrm{u}}_{C}^{\min }\right]}{\exp \left[f^{\wedge}\left(w^{b}, y^{b}, z^{b}, v^{b}\right)\right] \times \exp \left[\ln \hat{\mathrm{u}}_{C}^{b}\right]}=\frac{\hat{\mathrm{u}}_{C}^{\min }}{\hat{\mathrm{u}}_{C}^{b}}
\end{aligned}
$$

Minimum cost $\left(\hat{\mathbf{C}}^{\mathrm{min}}\right)$ is an optimal cost for the whole sample of microfinance institutions, so it indicated the frontier from the sample $-\hat{\mathrm{C}}^{\mathrm{b}}$ is actual cost of microfinance institution $B$. CostEff ${ }^{b}$ is proportion of cost or resources which is used efficiently. As an example, a bank with a cost-eff of $70 \%$ means that the financial institution operated efficiently as much as $70 \%$, and only $30 \%$ of the cost was wasted. Cost efficiency ranged between zero to one (0 to 1$)$, with the efficiency value equal to one indicated that the financial institution is the most efficient institution. 


\section{Jurnal Keuangan dan Perbankan \\ Volume 23, Issue 4, October 2019: 540-552}

\section{Results}

\section{Descriptive statistics}

The descriptive statistical analysis describes the character of the data sample used in this study. The data used in this study were 15 agribusiness microfinance institutions observed with financial data for two years, which are in 2016 and 2017. The descriptive statistic can be seen in Table 2, which illustrating average value, minimum, maximum, and deviation standard of every independent as well as dependent variables.

Based on Table 2, total cost (TC) year 20162017 of 15 agribusiness microfinance institutions presenting the average value of IDR 5,412,925 with deviation standard of IDR 6,938,483. The minimum value of total cost amounting to $\mathrm{Rp} 800.000$,- and maximum value of total cost of agribusiness microfinance institution amounting to $\mathrm{Rp}$ 26.475.000,-. The highest cost came from the agribusiness microfinance institution of "Rukun Tani". Meanwhile, most of agribusiness microfinance institutions' total cost range in Bogor District ranged between IDR 1,000,000,- up to IDR 5,000,000 per year.

Labor cost variable (Price of Labor/PLB) is one of the variables which influences the most to the total cost, which can be interpreted as an efficiency value of agribusiness microfinance institutions' cost. The average value of labor cost is IDR $3,055,833$,- with a deviation standard of 2.985.945,. A minimum value of labor cost amounting to IDR 800,000 per year. The cost is considered to be very small compared to the services provided by the board member and employee to the customer per year. While maximum value of labor cost amount- ing to IDR $10,800,000,-$ contributed by agribusiness microfinance institution "Rukun Tani". This cost addressed to board members and employee which consisted of 4 (four) people for 1 (one) year.

The output variable is the total loan given (Gross Loan Portfolio/GLP) by agribusiness microfinance institution to the member of the cooperation and society during the year 2016 to 2017. The average value of agribusiness microfinance institutions' total loan amounting to 59.976.033,- with a standard deviation of IDR $73,097,053$. As for the minimum value of total loan given by agribusiness microfinance institution is amounting to IDR $5,000,000$; meanwhile, the maximum value is IDR $289,000,000$.

The other influential variable which affected the total cost is the total capital variable (Total Equity/TEQ). The average value of equity possessed by 15 agribusiness microfinance institutions was IDR $123,273,144$ with deviation standard of IDR $37,001,830$,. The minimum value of capital owned by an agribusiness microfinance institution is IDR $101,150,000$. Meanwhile, the maximum value of capital owned by agribusiness microfinance institutions is amounting to IDR 260,635,000.

\section{Cost function Analysis with Stochastic Frontier Analysis (SFA) Model}

Efficiency level analysis of the agribusiness microfinance institution is using a stochastic frontier analysis (SFA) panel model with a pooled data method, which is a model that combined cross-section data with time series. Theoretically, there are several benefits obtained by using the data combi-

Table 2. Descriptive statistic

\begin{tabular}{lrrrr}
\hline \multicolumn{1}{c}{ Variable } & \multicolumn{1}{c}{ Min } & \multicolumn{1}{c}{ Max } & \multicolumn{1}{c}{ Mean } & \multicolumn{1}{c}{ Std } \\
\hline Total Cost (TC) & 800,000 & $26,475,000$ & $5,412,925$ & $6,938,483$ \\
Price of Labour (PLB) & 800,000 & $10,800,000$ & $3,055,833$ & $2,985,945$ \\
Gross Loan Portfolio (GLP) & $5,000,000$ & $289,000,000$ & $59,976,033$ & $73,097,053$ \\
Total Equity (TEQ) & $101,150,000$ & $260,635,000$ & $123,273,144$ & $37,001,830$ \\
\hline
\end{tabular}


nation referred above. The bigger number of observation possessed for the benefit of population estimation, thus would bring positive impact by enlarge degree of latitude and degrade collinearity probability between the independent variable (Hartono, 2009).

Based on estimation result of agribusiness microfinance institutions' cost function (Table 3), from the testing result of the entire variable through total cost by using result value of Chi-Square statistical test (Wald Chi2) as much as 366.28 and P-value (Prob>chi2) as much as 0.0000 thus it can be concluded that there were simultaneous/conjunctly influence of all independent variables to dependent variables (Total cost) due to the P-value $<0.05$. In terms of testing each independent variable to measure the presence or absence of influence to the dependent variable can be seen on each P-value of each variable. In Table 3, the labor cost variable was having a P-value of 0.0000 , while the total loan variable has a P-value of 0.066 , which means the whole significant variable on the level of confidence under 10 percent. The increase or decrease of labor cost variable, total loan, and equity will influence the escalation or degradation of total cost equal to the coeffi- cient of each variable. The entire estimation coefficient in the model of labor cost, total loan and equity obtained in terms of the natural logarithm, therefore these estimation coefficients are the elasticity value of cost through of the entire factors (Ana, 2012).

Table 3. Estimation result of the cost function

\begin{tabular}{lcc}
\hline \multicolumn{1}{c}{ Variable } & $\begin{array}{c}\text { Estimation } \\
\text { Coefficient }\end{array}$ & P-value \\
\hline Constant & -9.32 & 0.019 \\
InPLB & 0.78 & 0.000 \\
LnGLP & 0.28 & 0.000 \\
LnTEQ & 0.43 & 0.066 \\
\hline Wald Test & 366.28 & \\
Log Likelihood & -1.67 & \\
Prob $>$ chi2 & 0.0000 & \\
\hline
\end{tabular}

\section{Analysis of cost efficiency of agribusiness microfinance institution}

An agribusiness microfinance institution on a certain period of time can be categorized as efficient if the value is approaching one (1); or inefficiency if the value is approaching zero (0). The estimation result by using the Stochastic Frontier Analy-

Table 4. Cost efficiency level of agribusiness microfinance institution

\begin{tabular}{|c|c|c|c|}
\hline \multirow{2}{*}{$\begin{array}{c}\text { Agribusiness } \\
\text { Micro Finance Institution }\end{array}$} & \multicolumn{2}{|c|}{$\begin{array}{c}\text { Cost Efficiency Level } \\
\end{array}$} & \multirow{2}{*}{ Changes } \\
\hline & Year 2016 & Year 2017 & \\
\hline Rukun Tani & 0.997864 & 0.997859 & -0.000005 \\
\hline Sadar Tani & 0.997854 & 0.997855 & 0.000001 \\
\hline Ranji Mukti & 0.997864 & 0.997859 & -0.000005 \\
\hline Plamboyan & 0.997855 & 0.997878 & 0.000024 \\
\hline Usaha Tani & 0.997851 & 0.997857 & 0.000006 \\
\hline Sukagalih & 0.997855 & 0.997863 & 0.000008 \\
\hline Tajur Tani & 0.997874 & 0.997853 & -0.000021 \\
\hline Harum Manis & 0.997877 & 0.997859 & -0.000019 \\
\hline Mandiri Jaya & 0.997871 & 0.997861 & -0.000010 \\
\hline Tani Berkah & 0.997861 & 0.997871 & 0.000010 \\
\hline Medal Sari & 0.997877 & 0.997883 & 0.000006 \\
\hline Pandan Wangi & 0.997864 & 0.997863 & 0.000000 \\
\hline Antanan & 0.997846 & 0.997844 & -0.000002 \\
\hline Sejahtera & 0.997861 & 0.997860 & -0.000001 \\
\hline Jaya Bakti & 0.997853 & 0.997883 & 0.000030 \\
\hline Average & 0.997861 & 0.997863 & 0.000002 \\
\hline
\end{tabular}


sis (SFA) approach was selected from the best estimation result based on cost efficiency value. The higher efficiency value of an agribusiness microfinance institution indicating that the better efficient level of the agribusiness microfinance institution in managing its input factors, which will be utilized for financing. Table 4 presenting the result of cost efficiency calculation.

Based Table 4, agribusiness microfinance institution has been very efficient, with the value of efficiency of 99\% in 2016 and 2017. The value of efficiency of $99 \%$ means the whole agribusiness microfinance institutions have already capable of optimizing the use of resources available in minimizing cost. After conducting a comparison over the entire agribusiness microfinance institutions, the highest efficiency value in 2016 and 2017 was achieved by "Medal Sari" agribusiness microfinance institution. Although the agribusiness microfinance institution was categorized from having a smallcapitalization value, it is relatively very efficient compared to other agribusiness microfinance institutions possessing bigger capital.

The efficiency level of the agribusiness microfinance institution period 2016 - 2017, indicating a relatively stable trend. In 2016, the average of cost efficiency value of agribusiness microfinance institution in Bogor District was as much as 0.997861. While in 2017, the average of cost efficiency value of agribusiness microfinance institution in Bogor District was as much as 0.997863. Between 2016 and 2017, an improvement in cost efficiency average value has occurred of 0.000002 . The average cost efficiency value of agribusiness microfinance institutions in Bogor District was almost approaching 1; it indicated that the efficiency level of agribusiness microfinance institutions in Bogor District was relatively very high.

\section{Discussion}

Based on the estimation result in Table 3, the variable influence the most to total cost was Price of Labor/PLB. Estimation result indicated a labor cost coefficient of 0.78 , which means every increase in the labor cost of one percent will escalate the total cost of 0.78 percent, ceteris paribus. If the agribusiness microfinance institution wanted to increase its efficiency, then the agribusiness microfinance institution must be more effective in issuing labor costs. Agribusiness microfinance institutions' labor cost mostly obtain from the profit of AMFI's loan service within a year. However, there were two agribusiness microfinance institutions that distributed their labor cost each month, namely the agribusiness microfinance institution of "Rukun Tani" and "Mandiri Jaya". These labor costs were given to the main manager and administration officer.

Another variable is the Gross Loan Portfolio/GLP variable, which given to the member of the agribusiness microfinance institution, which has an elasticity value of 0,28 . This value defines that if there is an increase of financing/loan of 1 percent, the total cost will be predicted to have increment as well around 0,28 percent, ceteris paribus. The growth of loan volume generally indicating an increment from 2016 to 2017; however, there were 7 (seven) agribusiness microfinance institutions experienced loan volume degradation, namely AMFI Sadar Tani, Usaha Tani, Suka Galih, Harum Manis, Tani Berkah, Sejahtera and Pandan Wangi. The decrease of gross loans portfolio was due to the accu-

Table 5. Cost Efficiency Statistic based on the value of mean, std, minimum, maximum

\begin{tabular}{ccccc}
\hline Cost Efficiency & Minimum & Maximum & Mean & Std. Deviation \\
\hline 2016 & 0.997846 & 0.997877 & 0.997861 & 0.000010 \\
2017 & 0.997844 & 0.997883 & 0.997863 & 0.000011 \\
\hline
\end{tabular}




\section{Efficiency and sustainability of microfinance: Study case agribusiness microfinance institutions in Bogor Triane Widya Anggriani, R. Nunung Nuryartono, Bambang Juanda², Jaenal Effendi}

mulation of bad debt failing capital assistance rotation among members. Thus the capital turnover sustainability decrease as well. An assumption that capital assistance as grants from the government, causing most of the farmers to disincline to return the loan. The bad debt issue is the obstacle which very much affected the financial unsustainability of the agribusiness microfinance institution.

Another variable that influences total cost is the total capital/equity. The estimation result shows that the total capital coefficient of 0.43 , which means every increase of the capital amount of one percent, would increase the total cost of 0.43 percent, ceteris paribus. This indicated that most agribusiness microfinance institutions experienced an obstacle in terms of loan rotation to the farmers. Congestion of the return grade is the problem that causes the subsequent total loan to decrease.

Furthermore, if we observed the development of the capital amount of the agribusiness microfinance institution in Bogor District from 2016 to 2017, showing that the capital amount of AMFI was relatively stagnant. There were no significant additions to the capital amount. Another most prominent problem of agribusiness microfinance institutions is the limitation of capital. So that the debt capital turnover among members becomes lessen.

If we observed the progress of efficiency value from 2016 to 2017, there were seven agribusiness microfinance institutions that experience efficiency value degradation. The degradation of efficiency value was caused by the presence of other investments by AMFI to add their assets, such as computer purchases. However, overall, the average efficiency value of agribusiness microfinance institutions increase from 2016 to 2017. The performance of agribusiness microfinance institution in Bogor District has shown an excellent performance.

Based on estimation results, agribusiness microfinance institutions appeared to already man- age their best effort in compressing costs. It was obviously visible from AMFIs' efficiency value, which considered to be very efficient with an average of 0,997937. However, in reality, the agribusiness microfinance institutions in Bogor District encounter sustainability problems, which was marked with the degradation of total loan in several agribusiness microfinance institutions, as well as the amount of capital which relatively stable at the observed two years. A relatively low labor wage cost suspected as one of the causes unsustainability of agribusiness microfinance institutions in Bogor District. From the interview result with several agribusiness microfinance institutions, their workers averagely were paid only amounting to one to two million Rupiah per employee for one year. The small incentive caused many of the administrators to lose focus in operating the financial service business of agribusiness microfinance institutions. Besides the governments' grants factor, also small incentive factor which causes AMFIs' employee losing their focus in operating AMFIs' financial service business. This study is in accordance with the research conducted by Gul, Podder, \& Shahriar (2017), which stated that a low incentive to microfinance institutions' administrators, causing the unsustainability of the microfinance institution. Anyhow, microfinance institutions' administrators played an important role in ensuring microfinance institutions' success, so they must be given an adequate incentive (Aubert, de Janvry, \& Sadoulet, 2009). The incentive that can be given to AMFIs' administrator (credit agent) can be in the form of bonuses according to members' collection achievement or microfinance institutions' profit additional. A special incentive to administrator and board member (credit agent) will help them more motivated and encourage them to work more viable, hence trying to continue improving microfinance institutions' work performance. 


\section{Conclusion, Limitations, and Suggestions Conclusion}

Based on the study result conducted, we can conclude that 15 agribusiness microfinance institutions in Bogor District have a relatively high-efficiency level. Labor cost is a very responsive variable to the total cost. Most agribusiness microfinance institutions' expenses were spent to pay labor costs. However, if we viewed from the value, agribusiness microfinance institutions' labor cost considered relatively low, ranged between one million to two million Rupiah per employee for one year. This study also discovers several agribusiness microfinance institutions suffering unsustainability, which was indicated with loan volume degradation and limited capital possession. This is due to happen as a consequence of a low return grade of the loan, which boils down to inhibited capital turnover. Besides that, the low rate of wages made agribusiness microfinance institutions' administrators not focus on developing AMFI's business. It is necessary to consider giving away other incentives as additional to agriculture microfinance institution administrators' bo- nuses as a reward for their extra dedication to work. An optimal incentive will encourage administrators and employees to improve their work performance, which in the end, implicated agribusiness microfinance institutions' revenues.

\section{Limitations and suggestions}

Other limitations perceive by agribusiness microfinance institutions, many of them were having a restriction of capital due to the difficulties of fund mobilization back from society. To overcome the capital problem, agribusiness microfinance institutions' needed to conduct cooperation with a commercial bank to obtain additional capital loan aid with low-profit sharing. The limitation of this study is the small number of samples observed; thus, the research tends to be exclusive, which leads to a generalization of results becomes more limited only at the scope of Bogor District. Advance research is suggested to expand this research by conducting analysis and comparison between the district or province.

\section{References}

Ana, L. (2012). Efisiensi bank-bank merger dan akuisisi di Indonesia. Thesis. IPB University.

Anantanyu, S. (2011). Kelembagaan petani: Peran dan strategi pengembangan kapasitasnya.Jurnal Sosial Ekonomi Pertanian dan Agribisnis, 7(2), 102-109.

Armendariz, B., \& Labie, M. (2011). The handbook of microfinance. Singapore: World Scientific Publishing Co. Pte. Ltd.

Arsyad, L. (2008). Lembaga Kenangan Mikro. Institusi, kinerja dan Sustainabilitas. Yogyakarta: Penerbit Andi.

Aubert, C., de Janvry, A., \& Sadoulet, E. (2009). Designing credit agent incentives to prevent mission drift in pro-poor microfinance institutions. Journal of Development Economics, 90(1), 153-162. https://doi.org/10.1016/j.jdeveco.2008.11.002

BPS (Badan Pusat Statistik-Statistics Indonesia). (2016). West Java province in figures. Bandung.

BPS (Badan Pusat Statistik-Statistics Indonesia). (2017). Bogor regency in figures. Bogor.

Bakhtiari, S. (2006). Microfinance and poverty reduction: Some international evidence. International Business \& Economics Research Journal, 5(12), 65-71. https://doi.org/10.19030/iber.v5i12.3550 


\section{Efficiency and sustainability of microfinance: Study case agribusiness microfinance institutions in Bogor}

Triane Widya Anggriani, R. Nunung Nuryartono, Bambang Juanda ${ }^{2}$, Jaenal Effendi

Berger, A. N., \& Humphrey, D. B. (1997). Efficiency of financial institutions: International survey and directions for future research. European Journal of Operational Research, 98(2), 175-212. https://doi.org/10.1016/s0377-2217(96)00342-6

Berger, A. N., \& Mester, L. J. (1997). Inside the black box: What explains differences in the efficiencies of financial institutions? Journal of Banking and Finance, 21(7), 895-947. https://doi.org/10.2139/ssrn.138159

Sim J., \& Prabhu V. V. (2014). The sustainability and outreach of microfinance institutions. IFIP Advances in Information and Communication Technology, 439, 286-293. https://doi.org/10.1007/978-3-662-44736-9_35

Dumilah, R., Juanda, G., \& Khayatun Nufus. (2017). Analisis Efisiensi Biaya dengan Pendekatan Stochastic Frontier Analysis pada KBMT Kota Tangerang Selatan. Membangun paradigma kehidupan melalui multidisiplin ilmu. Pascasarjana Universitas Pamulang.

Fitzpatrick, T., \& McQuinn, K. (2005). Cost efficiency in UK and Irish credit institutions. The Economic and Social Review, 36(1), 45-66.

Gul, F. A., Podder, J., \& Shahriar, A. Z. M. (2017). Performance of microfinance institutions: does government ideology matter? World Development, 100, 1-15. https://doi.org/10.1016/j.worlddev.2017.07.021

Hartarska, V., Shen, X., \& Mersland, R. (2013). Scale economies and input price elasticities in microfinance institutions. Journal of Banking \& Finance, 37(1), 1-42. https://doi.org/10.1016/j.jbankfin.2012.08.004

Hartono, E. (2009). Analisis efisiensi biaya industri perbankan Indonesia dengan menggunakan metode parametrik Stochastic Frontier Analysis. Tesis. Universitas Diponegoro.

Hermawan, H., \& Andrianyta, H. (2012). Lembaga Keuangan mikro agribisnis: Terobosan penguatan kelembagaan dan pembiayaan pertanian di perdesaan. Analisis Kebijakan Pertanian, 10, 143-158.

Hermes, N., Lensink, R., \& Meesters, A. (2011). Outreach and efficiency of microfinance institutions. World Development, 39(6), 938-948. https://doi.org/10.1016/j.worlddev.2009.10.018

Littlefield, E., Morduch, J., \& Hashemi, S. (2003). Is microfinance an effective strategy to reach the millennium development goals? Focus Note No. 24 CGAP.

Maesaroh, I. (2013). Analisis efisiensi biaya dengan menggunakan metode parametrik stochastic frontier analysis pada bank umum. Semnas Fekon: Optimisme Ekonomi Indonesia, 240-247.

Masood, T., \& Ahmad, M. I. (2010). Technical efficiency of microfinance in India: a stochastic frontier approach. Prajnan, XXXIX(3). https://doi.org/10.2139/ssrn.1689645

Mersland, R., \& Strøm, R. Ø. (2010). Microfinance mission drift? World Development, 38(1), 28-36. https://doi.org/10.1016/j.worlddev.2009.05.006

Morduch, J. (1998). Does microfinance really help the poor/ ? new evidence from flagship programs in Bangladesh. Research Program in Development Studies.

Mulyaningsih, Y. (2016). Analisis keberlanjutan, jangkauan dan dampak pembiayaan LKMS terhadap pengurangan kemiskinan rumah tangga tani di perdesaan Jawa Barat. Disertasi. IPB University.

Nachrowi, N., \& Usman, H. (2002). Penggunaan Teknik Ekonometrika. Jakarta: PT Raja Grafindo Persada.

Nuryartono, N., Anggraenie, T., \& Firdaus, R. S. (2012). Efficiency level of BPR: Study of stochastic frontier analysis with an approach of time varying decay. International Research Journal of Finance and Economics, 85(January), 6-13. 
Sim, J., \& Prabhu, V. V. (2014). The sustainability and outreach of microfinance institutions. IFIP Advances in Information and Communication Technology, 439 (Part 2), 286-293. https://doi.org/10.1007/978-3-662-44736-9_35

Suharyadi, \& Sumarto, A. H. (2017). Analisis efisiensi industri perbankan Indonesia dengan menggunakan metode parametrik distribution free approach. Jurnal Ilmiah Manajemen, VII(1), 80-96.

Usman, S., Suharyo, W. I., Soelaksono, B., Toyamah, N., Mawardi, M. S., \& Akhmadi. (2004). Keuangan mikro untuk masyarakat miskin: pengalaman Nusa Tenggara Timur. Jakarta. Lembaga Penelitian SMERU.

Yaron, J. (1994). What makes rural finance institutions successful? The World Bank Research Observer, 9, 4970.

Zeller, M., \& Meyer, R. L. (2002). The triangle of microfinance: financial sustainability, outreach, and impact. Baltimore and London: The Johns Hopkins University Press. 